\title{
PENGARUH PEMBERIAN MAKANAN TAMBAHAN PEMULIHAN (PMT-P) TERHADAP STATUS GIZI BALITA GIZI BURUK DI DINAS KESEHATAN KOTA SEMARANG TAHUN 2012
}

\author{
Farida Fitriyanti, Tatik Mulyati") \\ Program Studi Ilmu Gizi Fakultas Kedokteran Universitas Diponegoro \\ Jl.Dr.Sutomo No.14, Semarang, Telp (024) 8453708, Email : gizifk@undip.ac.id
}

\begin{abstract}
Background : Severe malnutrition is often happened in children under five. It is the most serious stage from process of malnutrition, especially energy and protein. Those do not appropriate with requirement and happen for a long time. Malnutrition is showed by weight and height where those have linear relation. And those are showed with z-score value by weight-for-height and weight-for-age. An effort to overcome malnutrition is Supplementary Feeding Program of Recovery (PMT-P) where its nutritional value has been measured. So that requirement can be achieved. Method : This study was included on community nutrition with observational research and cohort approach. Subjects were 22 malnourished children under five including on inclusion criteria in Department of Health in Semarang during 60 days (2months). PMT-P was given on formula and biscuit form. It has nutritional value which can contribute $70 \%$ of energy requirement and $80 \%$ of protein requirement in one day.

Result : There was different nutritional status before and after gving PMT-P based on weight-for-height and weight-for-age with $p=0.000$ and $p=0.002$. Difference of nutritional status based on weight-for-height happening after PMT-P was from $100 \%$ of very thin to $18.2 \%$ normal; $40.9 \%$ thin; and $40.9 \%$ very thin. Whereas it based on weight-for-age was from $86.4 \%$ severe malnutrition to $40.9 \%$ mild malnutrition. PMT-P also gived contribution of energy of $54.60 \pm 15.42 \%$ and protein of $79.17 \pm 37.75 \%$ from daily need.

Conclusion : PMT-P for 2 months gives effect for changing of nutritional status based on weight-for-height and weight-for-age of malnourished children under five. It gives contribution of energy of $54.60 \pm 15.42 \%$ and protein of $79.17 \pm 37.75 \%$.
\end{abstract}

Keywords : PMT-Pecovery; severe malnutrition; formula WHO F100

\begin{abstract}
ABSTRAK
Latar Belakang : Gizi buruk sering dialami oleh balita dan merupakan bentuk terparah dari proses kekurangan gizi terutama energi dan protein yang tidak sesuai dengan kebutuhan dalam jangka waktu lama. Gizi buruk ditunjukkan dengan BB dan TB yang mempunyai hubungan linier yang dinyatakan dengan nilai z-score berdasarkan BB/TB dan $B B / U$. Salah satu upaya untuk mengatasi gizi buruk dengan pemberian makanan tambahan pemulihan (PMT-P) yang nilai gizinya sudah terukur agar kebutuhan gizinya dapat terpenuhi.

Metode : Penelitian ini termasuk gizi masyarakat, dengan jenis penelitian observasional dan rancangan penelitian cohort. Subjek yang terpilih berjumlah 22 balita gizi buruk yang masuk dalam kriteria inklusi di Dinas Kesehatan Kota Semarang selama 60 hari (2 bulan). PMT-P yang diberikan dalam bentuk formula dan biskuit dengan nilai gizi terukur yang dapat memberikan kontribusi $70 \%$ dari kebutuhan energi dan $80 \%$ dari kebutuhan protein dalam sehari.

Hasil : Ada perbedaan status gizi balita sebelum dan setelah pemberian PMT-P berdasarkan BB/TB dan BB/U dengan nilai $p=0,000$ dan $p=0,002$. Perbedaan status gizi berdasarkan BB/TB yang terjadi setelah pemberian PMT-P yaitu dari 100\% balita sangat kurus menjadi 18,2\% normal, 40.9\% kurus, dan 40.9\% sangat kurus, sedangkan berdasarkan BB/U dari $86.4 \%$ balita gizi buruk menjadi $40.9 \%$ gizi kurang. Pemberian PMT-P juga memberikan kontribusi energi sebesar $54.60 \pm 15.42 \%$ dan protein $79.17 \pm 37.75 \%$ dari kebutuhan seharusnya dalam sehari.

Kesimpulan : PMT-P selama 2 bulan memberikan pengaruh terhadap perubahan status gizi berdasarkan BB/TB dan BB/U balita gizi buruk dengan kontribusi energi sebanyak $54.60 \pm 15.42 \%$ dan protein $79.17 \pm 37.75 \%$.
\end{abstract}

Kata kunci : PMT-Pemulihan; gizi buruk; formula WHO F100

\section{PENDAHULUAN}

Gizi buruk pada balita merupakan salah satu permasalahan pokok bangsa Indonesia karena berdampak pada rendahnya kualitas sumber daya manusia. Gizi Buruk pada balita disebabkan oleh kekurangan energi dan protein yang yang tidak sesuai dengan kebutuhan dalam jangka lama dan penyakit infeksi. ${ }^{1,2}$ Gizi buruk ditunjukkan dengan 
berat badan dan tinggi badan yang memiliki hubungan linier yang dinyatakan dengan $\mathrm{z}$-score berat badan menurut tinggi badan $(\mathrm{BB} / \mathrm{TB})$ dan berat badan menurut usia $(\mathrm{BB} / \mathrm{U})$ berdasarkan standar deviasi unit (<-3SD) dan ditetapkan oleh World Health Organization (WHO). ${ }^{3}$

Prevalensi gizi buruk pada balita secara nasional berdasarkan Riskesdas 2007 sebesar 5,4\% dan 4,9\% tahun 2010. Prevalensi gizi buruk berdasarkan penilaian status gizi BB/TB di Jawa Tengah pada tahun 2007 dan 2010 yaitu sebesar 4,7 dan $6,4 \%$, sedangkan berdasarkan $\mathrm{BB} / \mathrm{U}$ pada tahun yang sama adalah $4,0 \%$ dan $3,3 \%$, hal ini menunjukkan adanya penurunan sebesar $1,3 \%$. Sedangkan prevalensi di kota Semarang pada tahun yang sama yaitu menunjukkan penurunan sebesar $0,67 \%$ yaitu dari 1,68 menjadi $1,01 \%$, namun kasus gizi buruk masih tetap membutuhkan perhatian. $^{4,5,6}$ Pemberian makanan tambahan pemulihan merupakan salah satu upaya dalam mengatasi masalah gizi buruk. PMT-Pemulihan bertujuan memulihkan keadaaan gizi balita gizi buruk dengan cara memberikan makanan dengan kandungan gizi yang terukur agar kebutuhan gizi dapat terpenuhi. ${ }^{7}$

Gizi buruk yang terjadi pada balita sering dikaitkan dengan kurangnya energi dan protein dalam jangka waktu yang lama. Penelitian di kota malang menunjukkan bahwa pemberian PMT-Pemulihan dengan formula WHO/Modifikasi dapat memberikan pengaruh yang signifikan terhadap status gizi anak balita gizi buruk. Penelitian di Malawi memberikan makanan tambahan berupa RUTF dengan energi 175 $\mathrm{kkal} / \mathrm{kgBB} / \mathrm{hari}$, protein $5,3 \mathrm{gr} / \mathrm{kgBB} / \mathrm{hari}$ atau dapat memberikan kontribusi sebesar $75 \%$ kebutuhan energi dan $80 \%$ kebutuhan protein dalam sehari. Komposisi mikronutriennya identik dengan F-100 sebelum pengenceran yang telah sesuai dengan rekomendasi WHO untuk mengejar pertumbuhan terhadap balita gizi buruk menunjukkan ada pengaruh yang signifikan terhadap status gizi. ${ }^{8,9,21,22}$

PMT-Pemulihan diberikan kepada balita gizi buruk yang telah dipilih oleh Dinas Kesehatan Kota Semarang untuk dimasukkan ke dalam program penanggulangan gizi buruk berupa formula WHO F100 dengan energi 100 $\mathrm{kkal} / \mathrm{kgBB} / \mathrm{hari}$, protein 2,9 gram $/ \mathrm{kgBB} /$ hari dan biskuit sun sebagai tambahan dengan energi 103,2 kkal, protein 2,16 gram per 6 keping sajian atau dapat memberikan kontribusi sebesar 70\% kebutuhan energi dan $80 \%$ kebutuhan protein dalam sehari. ${ }^{4,10,22}$ PMT-Pemulihan ini dilaksanakan selama 60 hari (2 bulan), dan membutuhkan pertispasi keluarga, status gizi pada awal pemberian PMT-P dan penyakit infeksi selama pelaksanan.

Berdasarkan hasil penjaringan balita gizi buruk oleh Dinas Kesehatan Kota Semarang tahun 2012 terdapat 29 balita yang mengikuti program penanggulangan gizi buruk. Peneliti mencoba untuk meneliti bagaimanakah perbedaan status gizi pada balita gizi buruk sebelum dan sesudah pemberian makanan tambahan pemulihan (PMT-P) di Dinas Kesehatan Kota Semarang tahun 2012.

\section{METODE PENELITIAN}

Penelitian ini termasuk dalam ruang lingkup keilmuan gizi masyarakat yang dilakukan di Dinas Kesehatan Kota Semarang dan wilayah kota Semarang pada bulan April - Juni 2012. Jenis penelitian ini adalah penelitian observasional dengan rancangan penelitian Cohort.

Populasi target dalam penelitian ini adalah balita gizi buruk yang bertempat tinggal di wilayah kota Semarang, sedangkan populasi terjangkau adalah balita gizi buruk yang dirujuk ke Dinas Kesehatan Kota Semarang untuk mendapatkan PMT-Pemulihan. Usia balita yang masih dianggap kecil maka dalam penelitian ini orang tua/wali balita gizi buruk dipilih sebagai responden penelitian untuk mengetahui asupan makanan subyek saat dirumah. Balita yang diambil telah memenuhi kriteria inklusi yaitu bersedia mengisi informed consent, mengikuti program penanganan gizi buruk oleh DKK, balita memiliki status gizi buruk sebelum mendapatkan PMT, sedangkan kriteria eksklusinya yaitu balita dirawat di Rumah sakit, meninggal saat program berlangsung, dan pindah alamat. Berdasarkan kriteria inklusi dan eksklusi tersebut, dari 29 balita gizi buruk yang mengikuti program hanya 22 balita gizi buruk dapat menjadi sampel penelitian ini.

Variabel terikat penelitian ini yaitu status gizi balita gizi buruk, variabel bebas yaitu pemberian makanan tambahan pemulihan (PMT-P). Asupan energi, protein dan penyakit infeksi merupakan variabel perantara dalam penelitian ini karena merupakan faktor yang secara langsung mempengaruhi status gizi berdasarkan BB/TB dan BB/U. Formula susu yang diberikan dalam penelitian ini adalah formula 100 terdiri dari susu, gula pasir, minyak sayur, dan mineral mix sesuai komposisi formula dari WHO dengan energi 100 $\mathrm{kkal}$, protein 2,9 gram per $100 \mathrm{ml}$ dan biskuit sun sebagai tambahan dengan energi 103,2 kkal, protein 2,16 gram per 6 keping sajian., ${ }^{3,410}$ Komposisi tersebut dapat mengkontribusi $70 \%$ dari 
kebutuhan energi dan $80 \%$ dari kebutuhan protein dalam sehari. ${ }^{9,22}$

Data primer yang dikumpulkan meliputi identitas sampel, pengukuran antropometri tinggi badan dan berat badan, dan asupan PMT-P. Data primer berupa pengukuran antropometri tinggi badan menggunakan infantometer dengan ketelitian $0,1 \mathrm{~cm}$ dan berat badan menggunakan timbangan injak digital dengan ketelitian $0,1 \mathrm{~kg}$. Data berat badan diperoleh dengan menghitung selisih antara berat badan wali dan balita dengan berat badan wali. Bersamaan dengan itu dilakukan pengambilan data asupan PMT-P.

Penilaian asupan PMT menggunakan metode recall $1 \times 24$ jam. Penentuan frekuensi pemberian PMT-P (formula WHO F100) pada semua sampel dihitung berdasarkan berat badan per individu, kondisi balita pada saat pemeriksaan dan sesuai dengan kebutuhan energi, protein per individu selama 2 bulan dari ketentuan program yang seharusnya yaitu 6 bulan. Data primer dikumpulkan dengan cara kunjungan, pengamatan, pemeriksaan, recall, recad, serta wawancara. Pemberian paket PMT-P kepada setiap balita sampel dilakukan seminggu sekali setiap penimbangan di Puskesmas Pandanaran. Paket PMT-P disiapkan oleh Tim Peneliti serta mengajarkan kepada ibu balita sampel cara menyiapkan PMT-P agar mereka dapat menyiapkan sendiri. Bentuk makanan yang diberikan formula F100 dan apabila balita masih mengkonsumsi ASI, maka pemberian ASI tetap diteruskan dengan didampingi F100 dan makanan pendamping. Pemberian F100 diberikan sesuai dengan berat badan balita dan kondisi klinis balita. Kepatuhan ibu atau pengasuh dalam memberikan PMT-P diketahui dari hasil wawancara.

Pengolahan dan analisis data menggunakan program Statistical Package for Social Science (SPSS) ver. 17 for Windows. Status gizi berdasarkan nilai z-score $\mathrm{BB} / \mathrm{TB}$ dan $\mathrm{BB} / \mathrm{U}$ yang dihitung menggunakan software WHO Anthro 2005. Sementara data asupan konsumsi PMT-P dan asupan makan dianalisis menggunakan program nutrisurvey 2005. Analisis data menggunakan analisis statistik deskriptif untuk melihat gambaran karakteristik subyek, tingkat kebutuhan energi dan protein, kontribusi PMT-P, dan status gizi. Uji kenormalan data menggunakan metode Saphiro wilk. Perbedaan Z-score sebelum dan sesudah perlakuan dianalisis menggunakan uji Wilcoxon karena distribusi data tidak normal.

\section{HASIL PENELITIAN}

\section{Karakteristik subyek penelitian}

Karakteristik subyek penelitian menurut umur, jenis kelamin dan status gizi disajikan pada tabel 1 .

Table 1. Karakteristik subyek

\begin{tabular}{|c|c|c|}
\hline \multirow{2}{*}{ Karakteristik subyek } & \multicolumn{2}{|c|}{$\mathrm{N}=22$} \\
\hline & $\mathrm{N}$ & $\%$ \\
\hline \multicolumn{3}{|l|}{ Umur } \\
\hline $0-6$ bulan & 1 & $4.5 \%$ \\
\hline $7-12$ bulan & 3 & $13.6 \%$ \\
\hline $1-3$ tahun & 17 & $77.3 \%$ \\
\hline $4-6$ tahun & 1 & $4.5 \%$ \\
\hline \multicolumn{3}{|l|}{ Jenis Kelamin } \\
\hline Laki - laki & 13 & $59.1 \%$ \\
\hline Perempuan & 9 & $40.9 \%$ \\
\hline \multicolumn{3}{|l|}{$\begin{array}{l}\text { Status Gizi } \\
(\mathrm{BB} / \mathrm{TB})\end{array}$} \\
\hline $\begin{array}{l}<-3 \mathrm{SD} \text { (sangat kurus) } \\
(\mathrm{BB} / \mathrm{U})\end{array}$ & 22 & $100 \%$ \\
\hline <-3SD (gizi buruk) & 19 & $86.4 \%$ \\
\hline -3SD s/d <-2SD (gizi kurang) & 3 & $13.6 \%$ \\
\hline
\end{tabular}

Tabel 1 menunjukkan sebagian besar subyek dalam penelitian ini $77.3 \%$ berada pada kelompok umur 1-3 tahun dan sebanyak $59.1 \%$ berjenis kelamin laki-laki. Sedangkan status gizi subyek berdasarkan z-score $\mathrm{BB} / \mathrm{TB}$ dan $\mathrm{BB} / \mathrm{U}$ sebelum mendapatkan PMT-P berkategori status gizi sangat kurus $100 \%$ dan gizi buruk $86.4 \%$, gizi kurang $13.6 \%$.

Tingkat asupan energi dan protein sebelum mendapat PMT-P 
Tingkat asupan energi dan protein sebelum mendapatkan PMT-P disajikan pada tabel 2.

Tabel 2. Kategori tingkat asupan energi dan protein sebelum pemberian PMT-P

\begin{tabular}{lcccc}
\hline \multicolumn{2}{c}{$\begin{array}{c}\text { Kategori tingkat } \\
\text { asupan }\end{array}$} & $\mathbf{N}$ & Energi & Protein \\
\hline$<70 \%$ (defisit berat) & 21 & $95.5 \%$ & 15 & $68.2 \%$ \\
$70-79 \% \quad$ (defisit & 0 & $0 \%$ & 2 & $9.1 \%$ \\
sedang) & 1 & $4.5 \%$ & 3 & $13.6 \%$ \\
$80-99 \% \quad$ (defisit & & & & \\
ringan) (normal) & 0 & $0 \%$ & 2 & $9.1 \%$ \\
$>100 \%$ (n) & & & & \\
\hline
\end{tabular}

Tabel 2 menunjukkan sebelum pemberian PMT-P, sebagian besar balita mengalami defisit asupan energi dan protein. Sebanyak 21 balita (95.5\%) mengalami defisit energi berat dan 15

\section{Tingkat asupan energi dan protein setelah mendapat PMT-P}

Tingkat asupan energi dan protein setelah mendapatkan PMT-P disajikan pada tabel 3. balita $(68.2 \%)$ mengalami defisit protein berat.

Tabel 3. Kategori tingkat asupan energi dan protein setelah mendapatkan PMT-P

\begin{tabular}{|c|c|c|c|c|}
\hline \multirow{2}{*}{$\begin{array}{l}\text { Kategori tingkat } \\
\text { asupan }\end{array}$} & \multicolumn{2}{|c|}{ Energi } & \multicolumn{2}{|c|}{ Protein } \\
\hline & $\mathrm{N}$ & $\%$ & $\mathrm{~N}$ & $\%$ \\
\hline$<70 \%$ (defisit berat) & 3 & $13.6 \%$ & 0 & $0 \%$ \\
\hline $70-79 \%$ & 2 & $9.1 \%$ & 0 & $0 \%$ \\
\hline sedang) & 9 & $40.9 \%$ & 3 & $13.6 \%$ \\
\hline $\begin{array}{l}80-99 \% \\
\text { ringan) }\end{array}$ & & & & \\
\hline$>100 \%$ (normal) & 8 & $36.4 \%$ & 19 & $86.4 \%$ \\
\hline
\end{tabular}

Berdasarkan tabel 3, menunjukkan terdapat perubahan tingkat asupan energi yang mengalami defisit energi berat sebanyak 18 balita $(81.9 \%)$, diiringi dengan kenaikan asupan energi untuk kategori sedang, ringan, dan normal. Untuk tingkat asupan protein, tidak terdapat balita yang mengalami defisit protein berat setelah pemberian PMT-P.

Kontribusi PMT-P dan makanan terhadap kebutuhan energi dan protein

Kontribusi PMT-P terhadap kebutuhan energi disajikan pada gambar 1.

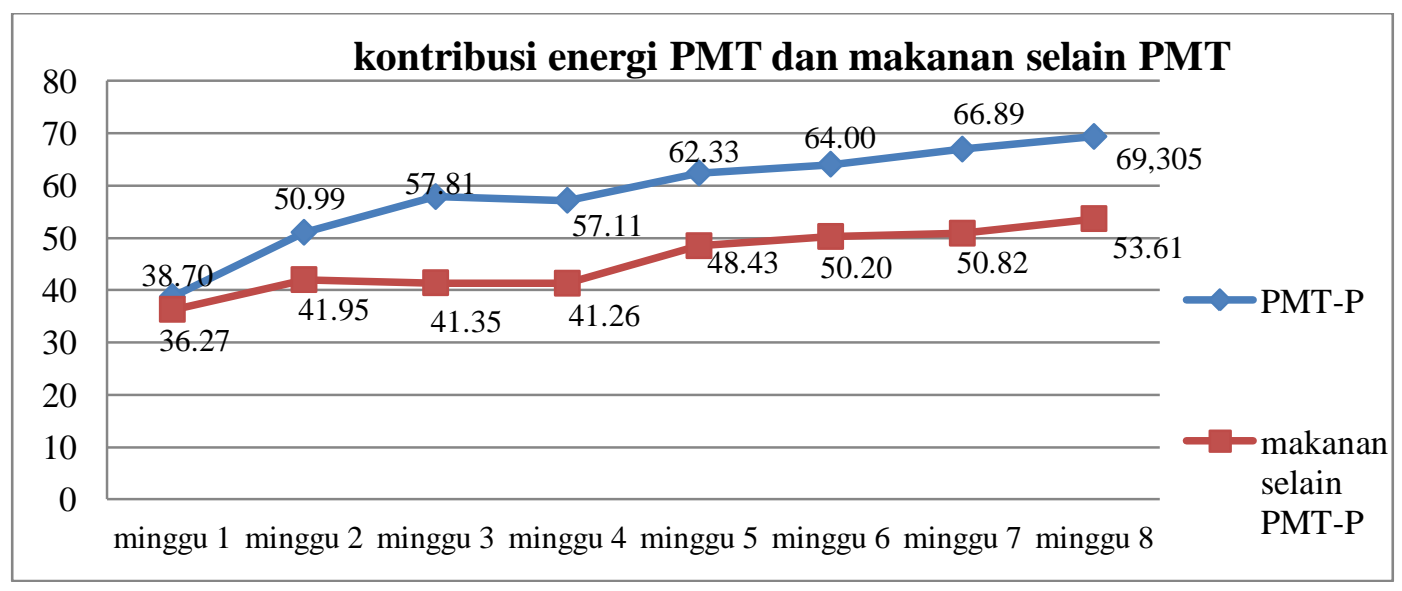

Gambar 1. Grafik kontribusi energi PMT dan makanan selama pemberian PMT-P

Kontribusi asupan energi PMT selama pemberian PMT-P dari minggu perminggu terjadi peningkatan dengan peningkatan tertinggi pada minggu ke delapan yaitu sebesar $69.30 \%$ dengan 
rerata kontribusi energi PMT-P adalah $54.60 \pm 26.04 \%$ kontribusi energi makanan adalah $49.09 \pm 27.42 \%$ dari kebutuhan energi. Asupan makanan selain PMT-P selama pemberian PMT-P juga terjadi peningkatan dimana pada minggu ke delapan terjadi peningkatan menjadi $53.61 \%$ dengan rerata

dari kebutuhan energi yang seharusnya. Sedangkan kontribusi protein PMT-P terhadap kebutuhan protein disajikan pada gambar 2 .

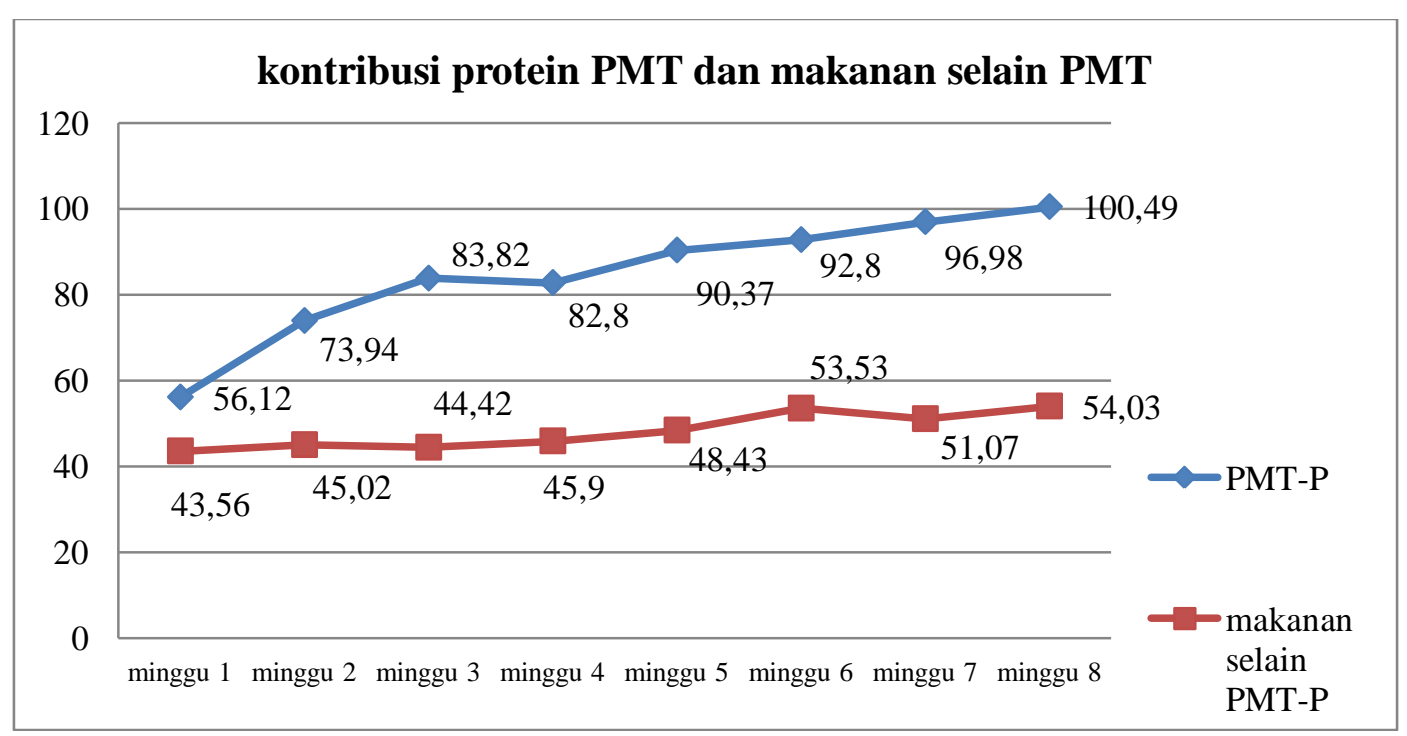

Gambar 2. Grafik kontribusi protein PMT dan makanan selama pemberian PMT-P

Kontribusi asupan protein PMT-P selama pemberian PMT-P dari minggu perminggu terjadi peningkatan dengan peningkatan tertinggi pada minggu ke delapan yaitu sebesar $100.49 \%$ dengan dengan rerata kontribusi protein PMT-P sebesar $79.17 \pm 37.75 \%$ dari kebutuhan protein yang seharusnya. Sedangkan asupan makanan selain PMT-P selama pemberian PMT-P terjadi peningkatan tertinggi pada minggu ke delapan yaitu sebesar $54.03 \%$ dengan kontribusi protein makanan sebesar $48.24 \pm 13.86 \%$ dari kebutuhan protein yang seharusnya.

Gambaran perubahan nilai z-score selama pemberian PMT-P

Perubahan nilai z-score selama pemberian PMT-P dapat dilihat pada gambar 3.

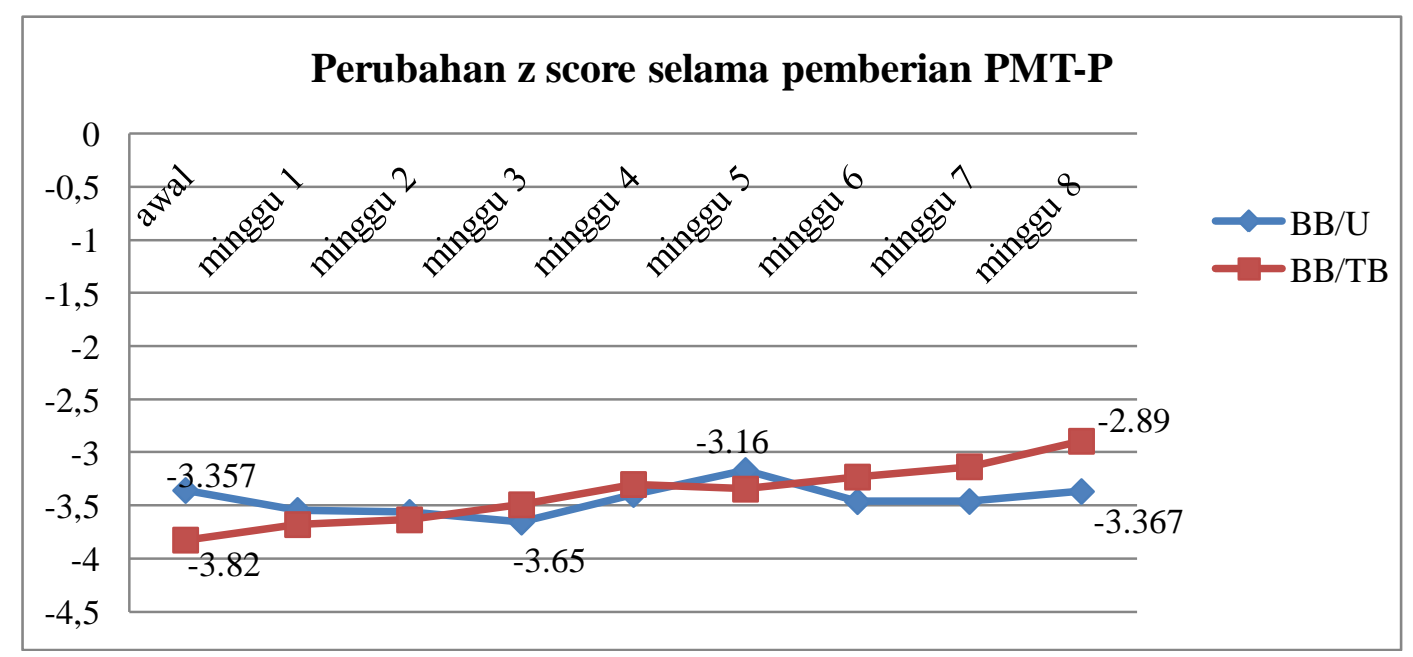

Gambar 3. Perubahan nilai Z-Skor selama pemberian PMT-P

Terjadi peningkatan nilai $\mathrm{z}$-score $\mathrm{BB} / \mathrm{TB}$ di setiap minggunya dengan nilai $\mathrm{z}$-score tertinggi pada minggu ke delapan yaitu -2.89 . Sedangkan nilai $\mathrm{z}$-score $\mathrm{BB} / \mathrm{U}$ meningkat pada minggu ke 6 yaitu -3.16, dan mengalami penurunan kembali pada minggu ke delapan menjadi -3.367 .

Pengaruh pemberian PMT-P terhadap status gizi 
Ada perbedaan status gizi berdasarkan BB/TB setelah pemberian PMT-P selama 60 hari yang bermakna dengan nilai $p=0,000$ yaitu dari $100 \%$ balita sangat kurus menjadi gizi kurus dan normal. Sedangkan status gizi berdasarkan BB/U terjadi perbedaan yang bermakna setelah pemberian PMT-P sebesar $p=0,002$ dengan menggunakan uji Wilcoxon yaitu dari $86.4 \%$ balita gizi buruk menjadi $40.9 \%$ gizi kurang.

\section{Perbedaan status gizi sebelum dan setelah pemberian PMT-P}

Perbedaan status gizi sebelum dan setelah pemberian PMT-P disajikan dalam tabel 4.

Tabel 4. Perbedaan status gizi (berdasarkan BB/TB) sebelum dan setelah pemberian PMT-P

\begin{tabular}{|c|c|c|c|c|}
\hline Kategori & $\begin{array}{c}\text { Sebelum } \\
(\mathrm{n}=22)\end{array}$ & $\%$ & $\begin{array}{c}\text { Sesudah } \\
(\mathrm{n}=22)\end{array}$ & $\%$ \\
\hline$<-3$ SD (severe wasted) & 22 & $100 \%$ & 9 & $40.9 \%$ \\
\hline$-3 \mathrm{SD} \quad \mathrm{s} / \mathrm{d} \quad<-2 \mathrm{SD}$ & 0 & $0 \%$ & 9 & $40.9 \%$ \\
\hline $\begin{array}{l}\text { (wasted) } \\
-2 \mathrm{SD} \mathrm{s} / \mathrm{d}+2 \mathrm{SD} \text { (normal) }\end{array}$ & 0 & $0 \%$ & 4 & $18.2 \%$ \\
\hline Total & 22 & $100 \%$ & 22 & $100 \%$ \\
\hline
\end{tabular}

Total subyek yang mengalami perubahan status gizi (BB/TB) $59.1 \%$ (13 balita), di mana 4 balita (18.2\%) mengalami peningkatan menjadi status gizi normal dan 9 balita (40.9\%) masih berstatus gizi kurus.

Tabel 5. Perbedaan status gizi (berdasarkan BB/U) sebelum dan setelah pemberian PMT-P

\begin{tabular}{lcccc}
\hline \multicolumn{1}{c}{ Kategori } & $\begin{array}{c}\text { Sebelum } \\
(\mathrm{n}=22)\end{array}$ & $\%$ & $\begin{array}{c}\text { Sesudah } \\
(\mathrm{n}=22)\end{array}$ & $\%$ \\
\hline$<-3$ SD (severe underweight) & 19 & $86.4 \%$ & 13 & $59.1 \%$ \\
-3SD s/d <-2SD (moderate & 3 & $13.6 \%$ & 9 & $40.9 \%$ \\
underweight) & 0 & $0 \%$ & 0 & $0 \%$ \\
-2SD s/d +2SD (normal) & & & & \\
\hline Total & $\mathbf{2 2}$ & $\mathbf{1 0 0 \%}$ & $\mathbf{2 2}$ & $\mathbf{1 0 0 \%}$ \\
\hline
\end{tabular}

Subyek yang mengalami perubahan status gizi (BB/U) 27.3\% (6 balita), dimana ke enam balita tersebut meningkat status gizi nya menjadi gizi kurang.

\section{PEMBAHASAN}

Jumlah balita yang masuk dalam program penanggulangan kasus gizi buruk di Dinas Kesehatan Kota Semarang sebanyak 29 balita, namun hanya 22 balita yang memenuhi kriteria inklusi. Selama penelitian, 1 subyek meninggal di rumah sakit setelah mengikuti 1 bulan pemulihan, 3 subyek pindah dari wilayah Semarang, dan 3 subyek drop out karena tidak mengikuti rangkaian kegiatan pemulihan. Studi yang dilakukan di Lampung pada anak balita gizi buruk menemukan $30.9 \%$ balita meninggal pada saat penelitian. ${ }^{11}$

Subyek penelitian berada pada kelompok umur 1-3 tahun (77,3\%) dan sebagian besar berjenis kelamin laki-laki $(59,1 \%)$. Jenis kelamin berkaitan dengan kebutuhan energi. Umumnya laki-laki memiliki berat dan panjang badan lebih tinggi dibandingkan dengan perempuan yang menyebabkan laki-laki memiliki kebutuhan energi dan protein yang lebih tinggi dan lebih berisiko untuk terkena gizi buruk dibandingkan perempuan. $^{12,13}$ Hal ini sesuai dengan laporan RISKESDAS 2010 mengenai prevalensi gizi buruk balita berdasarkan kelompok usia dan jenis kelamin, sebanyak $14.2 \%$ dari $40.8 \%$ balita yang berstatus gizi buruk, berada pada rentang usia 1-3 tahun dan dari $12 \%$ yang berstatus gizi buruk $6.3 \%$ berjenis kelamin laki-laki. ${ }^{6}$

Sebelum mendapatkan PMT-P status gizi balita yang dinilai berdasarkan BB/TB dan BB/U berada pada status gizi buruk dan mempunyai tingkat asupan energi dan protein pada defisit tingkat berat. Faktor penyebab gizi buruk berhubungan dengan pemberian makanan yang kurang memadai, pemberian ASI yang tidak eksklusif, dan terlambat memberikan makanan pendamping. ${ }^{18}$ Hasil wawancara dengan ibu dan pengasuh anak menunjukkan $25 \%$ balita mendapatkan ASI eklusif selama 6 bulan setelah lahir, selebihnya bayi langsung diberikan makanan 
dan minuman sebagai pendamping ASI dengan kondisi fisiologis balita belum mampu bekerja dengan sempurna untuk mencerna makanan. Makanan dan minuman yang biasa diberikan kepada balita antara lain madu, pisang, air teh, dan bubur susu. Asupan gizi yang adekuat berkaitan dengan kualitas dan kuantitas makanan yang diberikan. ${ }^{24,2,14}$ Jenis makanan yang biasa dikonsumsi balita dari hasil recall antara lain bubur beras, mie instan, bubur susu, pisang di mana makanan tersebut tidak memenuhi semua komponen zat gizi yang diperlukan untuk pertumbuhan dan perkembangan balita. Sementara dilihat dari kuantitasnya, jumlah makanan yang diberikan kepada balita tersebut tidak mencukupi kebutuhan sesuai dengan umur dan berat badan, rata-rata yang dikonsumsi sebanyak 3-4 sendok makan. Sedangkan untuk sumber protein yang dikonsumsi berupa ikan dan telur dengan jumlah yang rata-rata dikonsumsi sebanyak 10-15 gram.

Tubuh membutuhkan energi, karbohidrat, lemak dan protein dalam jumlah seimbang untuk pertumbuhan dan perkembangan. Apabila asupan energi kurang dari kebutuhan, tubuh akan menggunakan cadangan energi yang berupa glikogen dan lemak. Bila kekurangan energi berlangsung lama dan cadangan energi tidak mencukupi, maka protein digunakan sebagai sumber energi untuk menjalankan fungsi-fungsi vital dalam tubuh yang berdampak pada berkurangnya massa tubuh dan terhambatnya pertumbuhan. ${ }^{15,16,17}$ Kekurangan protein juga dapat mempengaruhi status gizi. Hal ini dikarenakan protein di dalam tubuh merupakan zat pembangun yang dibutuhkan tubuh untuk pertumbuhan, menggantikan sel-sel yang rusak, memelihara keseimbangan metabolisme tubuh, transport zat gizi dan pembentukan antibodi. ${ }^{18,19}$

Ada perbedaan status gizi berdasarkan $\mathrm{BB} / \mathrm{TB}$ dan $\mathrm{BB} / \mathrm{U}$ setelah pemberian PMT-P selama 60 hari. Hal ini disebabkan kontribusi asupan energi dan protein dari PMT-P yang diasup oleh balita mengalami peningkatan di setiap minggunya dan didukung dengan peningkatan asupan energi dan protein dari makanan selain PMT-P, sehingga tingkat asupan dalam sehari sebagian besar dapat terpenuhi. Rerata kontribusi energi dan protein pada PMT-P sebesar $54.60 \pm 26.04 \%$ dan $79.17 \pm 37.75 \%$ lebih besar dibandingkan dengan kontribusi asupan energi dan protein dari makanan selain PMT-P sebesar $49.09 \pm 27.42 \%$ dan $48.24 \pm 13.86 \%$. Pemberian PMT-P dalam bentuk formula atau cair mengandung semua nutrisi yang diperlukan balita gizi buruk, ditambah dengan vitamin, mineral dengan osmolaritas yang rendah dan dalam porsi kecil sehingga memudahkan balita dalam mengkonsumsi dan penyerapan nutrisi. Formula ini mengandung lemak nabati, whey, gula kompleks, mineral dan vitamin sehingga cocok untuk fase transisi pada balita gizi buruk yang membutuhkan makanan yang padat gizi untuk memperbaiki jaringan tubuh yang rusak (catch up). PMT-P yang diberikan mengandung protein yang mempunyai kandungan semua jenis asam amino esensial dalam proporsi yang sesuai untuk pertumbuhan sehingga lebih mudah diserap oleh tubuh dan keseimbangan komposisis ini tepat untuk perbaikan jaringan tubuh yang rusak. Lemak yang digunakan berupa lemak MCT yang mudah diabsorbsi dan dapat membantu meningkatkan penyerapan vitamin A, D, E, K. Lemak MCT cocok untuk balita gizi buruk yang proses pencernaan dan metaboliknya bermasalah karena pemecahan MCT sudah terjadi di rongga usus sehingga mengurangi penggunaan enzim lipase dari pankreas dan asam empedu sehingga penyerapan akan mudah meski dengan sedikit bantuan enzim. Sedangkan untuk kabohidrat berupa glukosa polimer (bebas laktosa) sehingga lebih mudah diabsorbsi oleh tubuh. Selain itu pada PMT-P juga mempunyai kandungan gizi berupa seng ( $\mathrm{Zn})$, kalium, magnesium dan tembaga $(\mathrm{Cu})$ yang dapat membantu dalam proses pertumbuhan balita. Seng (Zn), kalium, magnesium dan tembaga $(\mathrm{Cu})$ sangat dibutuhkan pada saat terjadi diare serta dehidrasi. Pada balita yang mengalami gizi buruk, penting untuk memperhatikan kepadatan nutrisi yang cukup dan seimbang agar fisiologis serta imunologi tubuh balita dapat kembali normal dan dapat meningkatkan berat badan. ${ }^{9,29,30}$ Penelitian yang dilakukan oleh Collins S dkk pada balita gizi buruk di Ethiopia pada tahun 2005 dengan pemberian paket makanan terapi siap makan (RUTF) berbentuk pasta setara dengan F100 dengan kontribusi energi dan protein sebesar $75 \%$ dari kebutuhan sehari selama 3 bulan menunjukkan $85 \%$ balita status gizi nya dapat berubah dengan nilai Z-score dari <-3SD menjadi >-2SD. ${ }^{22,23}$

Balita yang tidak mengalami perubahan status gizi dikarenakan selama pemberian PMT-P balita mengalami sakit demam, muntah, mual, batuk diare. Infeksi, imunitas dan gangguan pertumbuhan merupakan bagian yang saling berhubungan, dimana saat infeksi akan terjadi peningkatan kebutuhan energi, peningkatan katabolisme, nafsu makan menurun serta terjadi penurunana absorbsi zat gizi oleh usus. Rendahnya 
asupan gizi tersebut merupakan penyumbang terjadinya hambatan pertumbuhan (growth faltering) dan kejadian gizi kurang/gizi buruk. ${ }^{25,26}$ Penelitian lain oleh Gupta SS dan Monira S di India dan di Bangladesh melaporkan diare banyak dialami oleh anak malnutrisi karena terjadi inflamasi kronis pada lambung bagian bawah dan berkaitan dengan ulserasi usus dan lambung, selain itu balita malnutrisi juga sering mengalami infeksi saluran cerna sehingga berakibat pada malabsorbsi zat gizi dan penurunan kesehatan. ${ }^{27,28}$ Selain itu kesadaran, ketelatenan, dan kesabaran ibu dalam memberikan PMT-P masih kurang, dari hasil wawancara dengan responden, responden merasa jenuh dalam mengikuti PMT-P. Apabila dilihat dari tingkat asupan energi, setelah pemberian PMT-P masih terdapat balita yang mempunyai tingkat asupan energi defisit berat. Penurunan nafsu makan dapat mempengaruhi status gizi dan tingkat asupan energi dan protein, jika hal ini berlangsung dalam waktu yang lama maka dapat menurunkan berat badan. ${ }^{19,20}$

\section{KESIMPULAN}

PMT-P memberikan pengaruh yang signifikan terhadap perubahan status gizi berdasarkan $\mathrm{BB} / \mathrm{TB}$ dan $\mathrm{BB} / \mathrm{U}$ balita gizi buruk dengan memberikan rerata kontribusi energi sebanyak $54.60 \pm 15.42 \%$ dan protein $79.17 \pm 37.75 \%$ dari kebutuhan seharusnya dalam sehari.

\section{SARAN}

1. Untuk meningkatkan efisiensi paket PMT-P perlu dilaksanakan proses pendampingan secara kontinu, agar paket yang diberikan benar-benar tepat dan diterima sesuai dengan rencana program yang diberikan pada balita gizi buruk.

2. Kegiatan penyuluhan dan pemberian motivasi sangat diperlukan untuk meningkatkan pengetahuan dan kesadaran ibu responden terhadap status gizi balita.

\section{DAFTAR PUSTAKA}

1. Litbang Depkes. Gizi Buruk Sebabkan 3,5 juta Kematian Anak per Tahun; [17 Januari 2008]. www.litbang.depkes.go.id/aktual/anak/giziburuk.

2. Suhardjo. Perencanaan Pangan dan Gizi. Jakarta: Bumi Aksara; 2003.

3. Word Health Organization. Management Of Severe Malnutrition: A Manual For Physicians And Other Senior Health Workers. Geneva; 1999. Hal 4-14.
4. Dinas Kesehatan Kota Semarang. Data Seksi Gizi Dinas Kesehatan Kota Semarang 2010. Semarang : Dinas Kesehatan Kota Semarang; 2010.

5. Departemen Kesehatan RI. LAPORAN RISKESDAS 2007. Badan Penelitian dan Pengembangan Kesehatan Republik Indonesia. Jakarta; 2007.

6. Departemen Kesehatan RI. LAPORAN RISKESDAS 2010. Badan Penelitian dan Pengembangan Kesehatan Republik Indonesia. Jakarta; 2010.

7. Sugeng Iwan Setyobudi, Astutik Pudjirahayu, dan Bachtyar Bakri. Pengaruh PMT-Pemulihan dengan Formula WHO/Modifikasi terhadap Status Gizi Anak Balita KEP di Kota Malang. Jurnal Media Gizi dan Keluarga; 2005.

8. Michael AC, Heidi S, MacDonald JN, Per Ashorn, Andre B, Heather MC, Mark JM. Comparison of Home-Based Therapy With Ready-To-Use Therapeutic Food With Standard Therapy in The Treatment of Malnourished Malawian Children: A Controlled, Clinical Effectiveness Trial ${ }^{1-4}$. Am J Clin Nutr 2005;81:864-70.

9. Michael H. Golden. Proposed Recommended Nutrient Densities for Moderately Malnourished Children. Food and Nutrition Bulletin, vol.30, no.3. 2009, The United Nations University.

10. Dinas Kesehatan Kota Semarang. Data Seksi Gizi Dinas Kesehatan Kota Semarang 2012. Semarang : Dinas Kesehatan Kota Semarang; 2012.

11. Suhartono, Budiman D, Castro T. Pertumbuhan dan perkembangan anak gizi buruk masa lalu di Kabupaten Tanggamus Provinsi Lampung. Jurnal Gizi Klinik Indonesia 2008; 5(1): 41-8.

12. Diop el HI, Dossou N, Ndour M, Briend A, Wade S. Comparison of the efficacy of a solid ready-to-eat food and a liquit, milk-based diet for rehabilitation of severely malnourished children: a randomized trial. American Journal of Clinical 2003; 78(2): 302-307.

13. Gaboulaud V. Could nutritional rehabilitatiton at home complement or replace centre-based therapeutic feeding programmes for severe malnutrition. Journal of Tropical Pediatrics 2007; 53(1): 49-51.

14. Ari Yuliastuti. Gizi dan Kesehatan. Yogyakarta: Graha Ilmu ; 2008. Hal 11

15. Soekirman. Ilmu Gizi dan Aplikasinya untuk Keluarga dan Masyarakat. Jakarta: Penebar Swadaya; 2004.

16. Walker WA, John B Watkins, Christopher Duggan. Nutrition in pediatrics. Canada: BC Decker Inc.; 2003.

17. Martha, H. S. Biochemical and psycologycal Aspects of Human Nutrition. WB Sounders Company; 2000.

18. Amrahu S, Zemone T. risk factors for severe acute malnutrition children under the age of five: a case 
control study. Ethiop J Health Dev 2008; 22(1): $21-5$.

19. Caulfield LE, de Onis M, Black RE. Undernutrition as an underlying cause of child deaths associated with diarrhea, pneumonia, malaria, and measles. AM J Clin Nutr 2002; 80: 193-8.

20. Gibson RS. Principle of nutritional assessment. 2nd ed. New Yory: Oxford University press; 2005. p. 337.

21. WHO. Guidelines for the inpatient treatment of severely malnourished children. SEARO Technical Publication 2003; 24.

22. WHO. WHO Child Growth Standards Length/height-for-age, weight-for-age, weight-for-length, weight-for-height and body mass index-for-age Metods and Development. Departement of Nutition for Health and Development. Geneva; 2006.

23. Collins S, Sadler K, Dent N, Khara T, Guerrero S, Myatt M, Saboya M, Walsh A. Key Issues In The Success Of Community-Based Management Of Severe Malnutrition. Food and Nutrition Bulletin 2006; 27(3 Suppl):S49-82.

24. Masithah T, Soekiman, Martianto D. Hubungan pola asuh makan dan kesehatan dengan status gizi anak batita di Desa Mulya Harja. Media Gizi dan Keluarga. 2005; 29: 29-39.

25. Fatimah S. Dampak berat badan lahir terhadap status gizi bayi. Badan Litbang kesehatan [serial online]. 2009 [dikutip 2 Maret 2012]. Diunduh dari: http://diglib.litbang.depkes.go.id

26. Kusharisupeni. Peran status kelahiran terhadap stunting pada bayi: sebuah studi prospektif. Jurnal Kedokteran Trisakti. 2002; 23: 73-80.

27. Gupta SS, Mohammed MH, Ghosh TS, Kanugo S, Nair GB, Mande SS. Metagenome of the gut of a malnourished children. Gut pathogens. 2011; 3: 1-9.

28. Monira S, Nakamura S, Gotoh $\mathrm{K}$, Izutsu $\mathrm{K}$, Watanabe $\mathrm{H}$, Alam NH, et al. Gut microbiota of healthy and malnourished children in Bangladesh. Frontiers in microbiology. 2011; 2: 1-7.

29. Mahan L.K, Arlin, M.T. Krause's Food, Nutrition \& Diet Therapy. Edisi 11. Philadelphia: WB Saunders Co; 2000: 45.

30. Damayanti Rusli Sjarif, Endang Dewi Lestari, Maria Mexitalia, Sri sudaryati Nasar. Buku Ajar Nutrisi Pediatrik dan Penyakit Metabolik Jilid 1. Ikatan Dokter Anak Indonesia; 2011:20-59,106-147. 